\title{
PENYULUHAN DAN PEMBUATAN PAPER SOAP (SABUN KERTAS) BAGI MASYARAKAT DI KELURAHAN PEMATANG GUBERNUR KOTA BENGKULU UNTUK MENINGKATKAN KESADARAN MENCUCI TANGAN SEBAGAI LANGKAH AWAL PENCEGAHAN WABAH COVID-19
}

\author{
Risky Hadi Wibowo ${ }^{1}$, Sipriyadi ${ }^{1}$, Reza Pertiwi ${ }^{2}$, Thoriqul Hidayah ${ }^{1}$, \\ Della Indah Medani ${ }^{1}$, Gustina Dwi Wulandari ${ }^{1}$, Nadya Rosianti ${ }^{1}$
}

\author{
1Jurusan Biologi, Fakultas Matematika dan Ilmu Pengetahuan Alam, Universitas Bengkulu, Jl. W. R \\ Supratman, Kandang Limun, Bengkulu 38125 Indonesia \\ 2Program Studi Farmasi, Fakultas Matematika dan Ilmu Pengetahuan Alam, Universitas Bengkulu, Jl. W. \\ R Supratman, Kandang Limun, Bengkulu 38125 Indonesia \\ riskyhadiwibowo80@gmail.com
}

\begin{abstract}
The hand is the main transmission pathogen entry into the body, most often in direct contact with other limbs and surrounding objects. The importance of maintaining hand hygiene by always washing hands with soap is the first step in preventing transmission of COVID-19. However, during a pandemic like this, it will be difficult to find soap available everywhere and tends to be hard to carry all the time. Therefore, this service aims to invite the people of Pematang Gubernur, Bengkulu City, to use paper soap because it is easier to use its use and flexible to carry anywhere. Besides being an effort to prevent the COVID-19 outbreak, it can also add to new information and skills to make attractive soaps. The feedback response was given by the community service implementation team to the community service participants resulted in a positive response to this activity, who initially did not know about making and use of paper soap and became aware of this.
\end{abstract}

Keywords: Hand, Paper Soap, Coronavirus

\begin{abstract}
Abstrak
Tangan merupakan transmisi utama masuknya patogen ke dalam tubuh, Karena tangan merupakan anggota tubuh yang paling sering berkontak langsung dengan anggota tubuh lain dan benda-benda disekitar. Pentingnya menjaga kebersihan tangan dengan selalu mencuci tangan menggunakan sabun merupakan langkah awal dalam pencegahan penularan COVID-19. Namun ditengah pandemi seperti ini akan sulit untuk menemukan ketersediaan sabun di semua tempat dan cenderung susah untuk dibawa setiap saat. Oleh sebab itu pengabdian ini bertujuan mengajak masyarakat di Kelurahan Pematang Gubernur Kota Bengkulu untuk menggunakan Paper soap (sabun kertas) karena dinilai lebih mempermudah dalam penggunaannya dan fleksibel untuk dibawa kemana saja selain menjadi upaya pencegahan wabah COVID-19, juga dapat menambah informasi baru dan keterampilan untuk para warga dalam membuat sabun yang menarik. Respon umpan balik yang diberikan tim pelaksana pengabdian kepada peserta pengabdian menghasilkan respon positif terhadap kegiatan ini, yang awalnya belum mengetahui pembuatan dan penggunaan sabun kertas menjadi tahu akan hal tersebut.
\end{abstract}

Kata kunci: Corona virus, Paper soap (Sabun Kertas), Tangan 


\section{PENDAHULUAN}

\begin{tabular}{cccc}
\multicolumn{2}{c}{ Pneumonia corona virus } \\
(COVID-19) yang
\end{tabular}
dilaporakan dari Wuhan, Tiongkok telah menyebar ke seluruh Tiongkok bahkan ke seluruh dunia. Kasus terkonfirmasi positif COVID-19 telah membumbung hingga jumlah yang melebihi SARS pada tahun 2003, dan tingkat kematiannya tinggi. Virus umumnya dapat bertahan selama beberapa jam di permukaan

yang halus. Jika suhu dan kelembaban memungkinkan, mereka dapat bertahan selama beberapa hari. Virus corona baru sensitif terhadap sinar ultraviolet dan panas. Panas yang berkelanjutan pada $132,8^{\circ} \mathrm{F}$ selama 30 menit, eter, alkohol 75\%, desinfektan yang mengandung klorin, asam perasetat, kloroform, dan pelarut lipid lainnya dapat secara efektif menonaktifkan virus (Zhou, 2020).

Dari beberapa Negara yang sudah banyak terinfeksi oleh virus tersebut, tidak menutup kemungkinnanIndonesia masuk dalam daftar beberapa Negara yang mengalami dampak wabah COVID-19 tersebut. Salah satu daerah diIndonesia yang terkena wabah COVID-19 ialah Provinsi Bengkulu, dimana saat ini sudah ada warga Kota Bengkulu yang terkena virus COVID-19. Tercatat pada tanggal 12 April 2020 berdasarkan sumber data Tim Data COVID-19 P2P Dinas Kesehaatan Provinsi Bengkulu bahwa sudah ada 527 orang ODP (Orang Dalam Pemantauan), 15 orang PDP (Pasien Dalam Pengawasan), 3 orang pasien positif COVID-19, dan 1 orang meninggal dunia. Hal ini merupakan salah satu ancaman bagi masyarakat khususnya Kota Bengkulu agar dapat menjaga kesehatan sehingga terhindar dari virus COVID-19.

Tangan merupakan salah satu jalur masuknya kuman penyakit ke dalam tubuh karena tangan adalah anggota tubuh yang paling sering berhubungan atau berkontakan langsung dengan mata, hidung, dan mulut. Peran tangan sebagai sarana transmisi patogen talah disadari sejak 1840-an (Hammond dan Aii, 2000). Ada banyak penyakit yang bisa bersarang dalam tubuh bila lupa mencuci tangan, salah satunya adalah COVID-19. Penyakit-penyakit ini dengan mudah memasuki tubuh lewat tangan yang tercemar virus. Virus berpindah saat memegang pintu, menekan tombol lift, bersalaman, memegang uang, kursi atau barang apa saja.

Kulit adalah organ terluar tubuh yang membutuhkan perlindungan terhadap mikroorganisme patogen. Pentingnya dalam menjaga kebersihan tangan penting dilakukan untuk melindungi tubuh dari infeksi bakteri. Cara yang paling sederhana untuk menjaga kebersihan tangan adalah dengan mencuci tangan menggunakan sabun, antiseptik dan air (Joy, 2012).

Mencuci tangan tujuh langkah adalah tata cara lengkap mencuci tangan memakai sabun menggunakan air mengalir untuk membersihkan jari-jari, telapak tangan, punggung tangan serta pergelangan tangan dari semua kotoran, kuman serta bakteri penyebab penyakit. Seiring kemajuan teknologi sabun cuci tangan semakin berkembang yakni 
adanya sabun kertas antibakteri. Terlihat masih rendah nya kesadaran masyarakat maupun petugas media Indonesia pakai sabun, oleh karena itu program penyuluhan menjaga kebersihan dengan mencuci tangan merupakan salah satu cara mencegah penularan COVID-19 khususnya masyarakat di Kelurahan Pematang Gubernur, Kota Bengkulu. Oleh karena itu program pengabdian masyarakat ini ditujukan untuk mengajak masyarakat khususnya di Kelurahan Pematang Gubernur Kota Bengkulu untuk menggunakan Paper soap (sabun kertas) sekaligus di laksanakannya penyuluhan dan praktek pembuatan Paper soap (sabun kertas) kepada masyarakat sebagai salah satu langkah awal upaya pencegahan wabah COVID19 karena dinilai lebih mempermudah dalam penggunaannya dan fleksibel untuk dibawa kemana saja.

\section{METODE PELAKSANAAN}

Metode pelaksanaan pada program pengabdian masyarakat dengan judul penyuluhan dan pembuatan Paper soap (Sabun kertas) bagi masyarakat di Kelurahan Pematang Gubernur, Kota Bengkulu untuk meningkatkan kesadaran mencuci tangan sebagai langkah awal pencegahan wabah COVID-19 yaitu melalui tahap persiapan meliputi koordinasi tim terlebih dahulu dengan LPPM dan khalayak sasaran pengabdian untuk didapatkan surat perizinan di Kelurahan Pematang Gubernur, Kecamatan Muara
Bangkahulu, Kota Bengkulu, RT.22, RW.02.

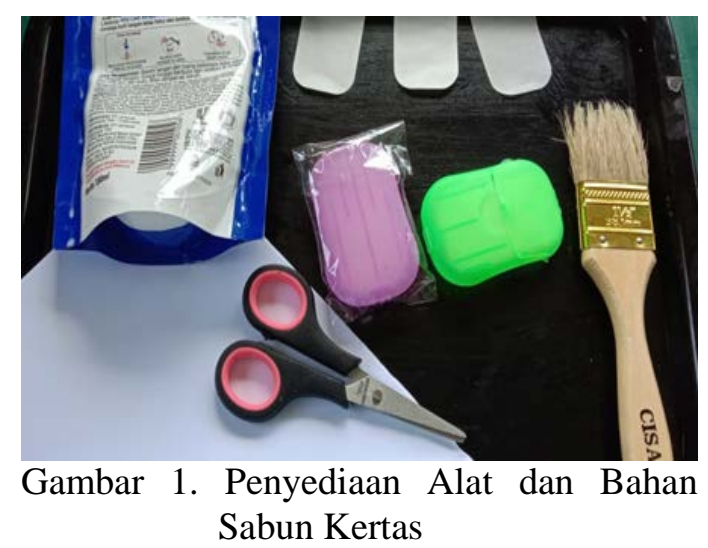

Tahap pelaksanaan meliputi sosialisai jadwal dan materi kegiatan di lokasi pengabdian, penyediaan alat dan bahan pembuatan sabun kertas dilokasi pengabdian seperti pada gambar diatas yaitu gunting, kuas, kertas hvs dan sabun cair. Menurut Salam (2003), sabun kertas dibuat untuk mempermudah konsumen membawanya kemana saja dengan mudah dan fleksibel. Pembuatan sabun kertas menggunakan berbagai macam kertas seperti kertas hvs yang sering ditemukan di fotocopi dan kertas minyak yang bahannya licin, halus dan mudah menyerap air.

Kegiatan pengabdian pada masyarakat (PPM) melalui beberapa tahap yag diawali dengan memberikan pendidikan dan pelatihan di lokasi pengabdian dilakukan dengan memberikan pengenalan Paper soap (kertas sabun) terlebih dahulu kepada warga dari segi, kemudian mengajari masyarakat teknik pembuatan dan penggunaan Paper soap (kertas sabun) serta manfaat penggunaan Paper soap (kertas sabun) tersebut. 


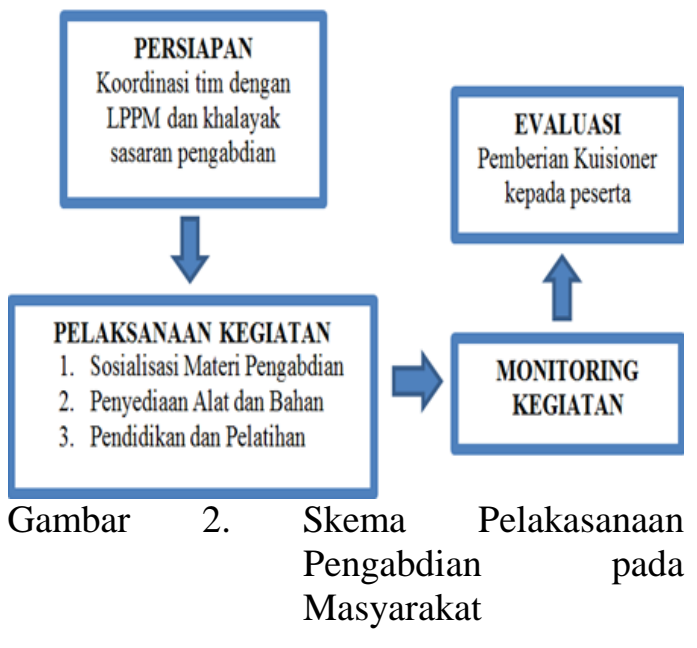

HASIL DAN PEMBAHASAN

Penyuluhan Materi Pengabdian

Program pengabdian pada masyarakat (PPM) tentang penyuluhan dan pembuatan Paper soap (Sabun kertas) dilaksanakan pada tanggal 7 November 2020, diawali dengan penyuluhan materi pengabdian bersama warga RT.22, RW.02 kelurahan pematang gubernur dengan peserta pengabdian sebanyak 15 orang terdiri dari orang tua dan remaja. Kegiatan tahap pertama PPM dilakukkan secara formal berupa penyampaian materi mengenai Paper Soap (Sabun Kertas) dan aplikasinya.

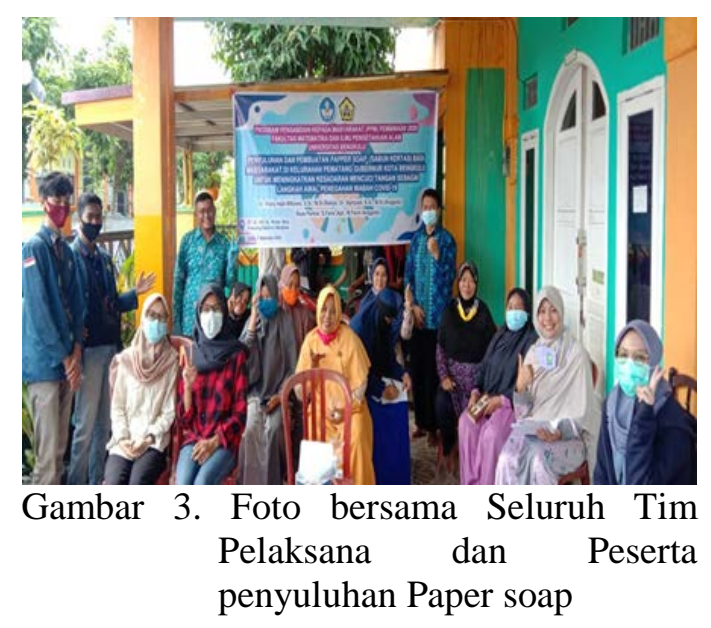

\section{Praktek Pembuatan Paper soap}

Tim pelaksana pengabdian mempraktekkan langsung kepada warga mengenai tahapan pembuatan sabun kertas yang diawali dengan pemberian sabun cair pada kertas Hvs, pengeringan kertas yang sudah diolesin sabun, setelah kering kertas digunting berbentuk segiempat dan dikemas dalam kemasan yang menarik. Setelah itu tim pelaksana memberi pengajaran kepada warga cara menggunakan sabun kertas. aplikasi pembuatan Paper Soap (Sabun Kertas).

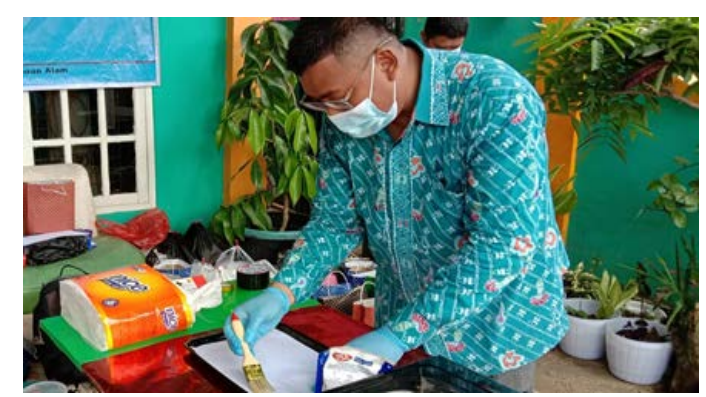

Gambar 4. Praktek pembuatan Paper soap (sabun kertas)

Kegiatan pengabdian selanjutnya yaitu dilakukan penjemuran bahan kertas yang sudah di oleskan sabun cair. Pada penjemuran ini untuk tetap menjaga kelembapan kertas, penjemuran dilakukan ditempat yang tidak terlalu terekspos sinar matahari

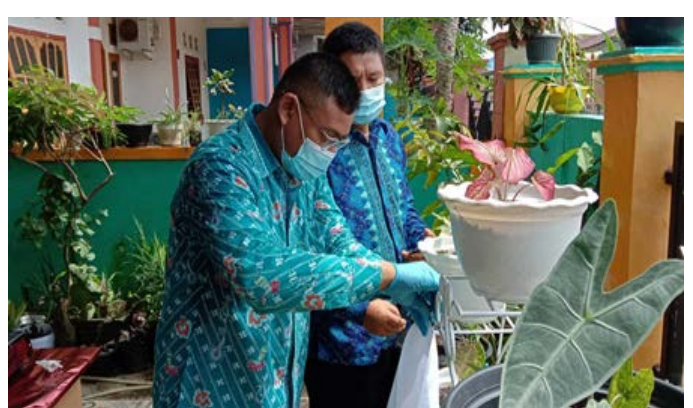

Gambar 5. Penjemuran bahan kertas sabun yang telah dioleskan sabun 


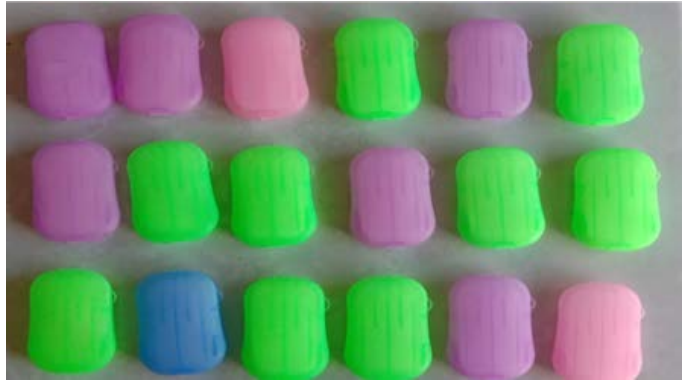

Gambar 6. Produk Akhir dari Kegiatan Penyuluhuan dan Pembuatan Paper soap (sabun kertas)

Pada sesi akhir acara pemberian cendera mata beserta produk sabun kertas kepada beberapa warga yang mengikuti acara pengabdian ini. Program pengabdian masyarakat tentang penyuluhan dan pembuatan sabun kertas diharapkan akan meningkatkan daya tarik warga dalam menggunakan sabun sebagai pembersih, maka itu sabun dikemas dalam bentuk yang menarik dan fleksibel digunakan, selain itu melahirkan kesadaran masyarakat akan pentingnya menjaga kebersihan tangan ditengah wabah COVID-19 yang satu satu penularannya melalui tangan. Menurut Salam (2003), didalam sabun terkandung surfaktan yang dapat mengikat kotoran dari permukaan kulit dan melarutkannya bersama air pada saat dibilas. sabun dapat mengangkat kotoran dari kulit.

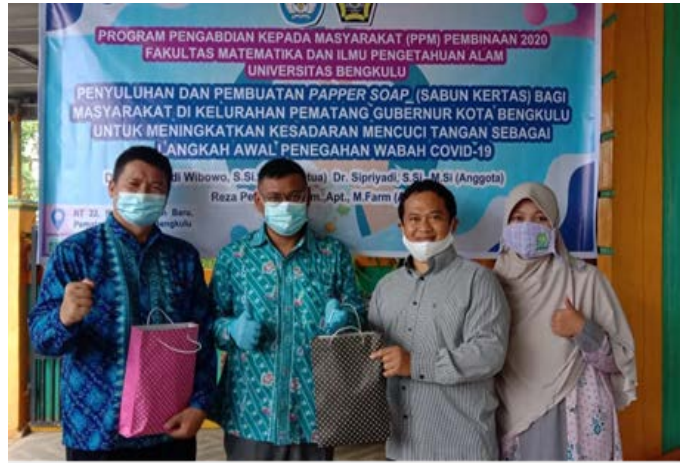

Gambar 7. Pemberian Cendera mata dari Tim Pelaksana Kepada Peserta Penyuluhan

\section{Umpan Balik Peserta}

Umpan balik peserta dilakukan sebagai bentuk evaluasi kegiatan pengabdian kepada masyarakat umpan balik tersebut dalam bentuk kuisioner. kuisioner berisi tujuah pertanyaan ganda seputar Paper soap (sabun kertas) kepada 15 peserta pengabdian. Menurut Noviana (2020), umpan balik peserta dilakukan sebagai evaluasi kegiatan pengabdian kepada masyarakat. Umpan balik peserta dilakukan dengan cara memberi kuesioner untuk menggambarkan peserta pengabdian telah paham terhadap materi penyuluhan tersebut

Tabel 1. Hasil Kuisioner Tahap Postest

\begin{tabular}{|c|c|c|c|c|}
\hline No & Soal & $\begin{array}{c}\text { Pilihan } \\
\text { jawaban }\end{array}$ & Frekuensi & Persentase \\
\hline \multirow[t]{3}{*}{1} & Apakah bapak/ibu mengetahui bahwa tangan & Tahu & 4 & $26,67 \%$ \\
\hline & merupakan transmisi pertama dari penularan & Ragu-ragu & 10 & $66,67 \%$ \\
\hline & wabah penyakit & Tidak tahu & 1 & $6,67 \%$ \\
\hline \multirow[t]{3}{*}{2} & Apakah bapak/ibu mengetahui pentingnya & Tahu & 15 & $100 \%$ \\
\hline & menjaga kebersihan tangan dengan selalu mencuci & Ragu-ragu & 0 & $0 \%$ \\
\hline & tangan menggunakan sabun & Tidak tahu & 0 & $0 \%$ \\
\hline \multirow[t]{3}{*}{3} & Apakah bapak/ibu mengetahui tata cara yang & Tahu & 10 & $66,67 \%$ \\
\hline & benar ketika mencuci tangan & Ragu-ragu & 4 & $26,67 \%$ \\
\hline & & Tidak tahu & 1 & $6,67 \%$ \\
\hline \multirow[t]{3}{*}{4} & Apakah bapak/ibu pernah mendengar atau & Tahu & 5 & $33,3 \%$ \\
\hline & mengetahui apa itu Paper soap (Sabun kertas) & Ragu-ragu & 6 & $40 \%$ \\
\hline & & Tidak tahu & 4 & $26,67 \%$ \\
\hline
\end{tabular}


5 Apakah bapak/ibu mengetahui cara membuat Paper soap (sabun kertas) secara sederhana

6 Apakah bapak/ibu mengetahui cara menggunakan Paper soap (sabun kertas)

7 Selain mencuci tangan, apakah bapak/ibu mengetahui cara menjaga daya tahan tubuh agar terhindar dari penularan wabah COVID-19

\begin{tabular}{ccc} 
Tahu & 2 & $13 \%$ \\
Ragu-ragu & 2 & $13 \%$ \\
Tidak tahu & 11 & $73 \%$ \\
Tahu & 10 & $66,67 \%$ \\
Ragu-ragu & 4 & $26,67 \%$ \\
Tidak tahu & 3 & $20 \%$ \\
Tahu & 11 & $73 \%$ \\
Ragu-ragu & 3 & $20 \%$ \\
Tidak tahu & 1 & $6,67 \%$ \\
\hline
\end{tabular}

Pemberian kuisioner dilakukan 2 tahap yaitu tahap pretest dan postest. Tahap pretest dilakukan sebelum penyuluhan pembuatan Paper soap (Sabun kertas), dari hasil kuisioner yang diberikan, didapatkan hasil sebagian besar peserta masih ragu bentuk penularan penyakit melalui tangan, namun seluruh peserta mengetahui pentingnya menjaga kebersihan tangan dengan sabun. Sebagian peserta sudah paham mencuci tangan yang benar dan sudah mengetahui sabun kertas, namun belum mengetahui cara penggunaanya. Untuk itu dilakukan praktek secara langsung oleh tim pengabdian kepada salah satu peserta pengabdian tersebut.

Tabel 2. Hasil Kuisioner Tahap Pretest

\begin{tabular}{|c|c|c|c|c|}
\hline No & Soal & $\begin{array}{c}\text { Pilihan } \\
\text { Jawaban }\end{array}$ & Frekuensi & Persentase \\
\hline \multirow[t]{3}{*}{1} & \multirow{3}{*}{$\begin{array}{l}\text { Apakah bapak/ibu mengetahui bahwa tangan } \\
\text { transmisi pertama dari penularan wabah } \\
\text { penyakit }\end{array}$} & Tahu & 12 & $80 \%$ \\
\hline & & Ragu-ragu & 3 & $20 \%$ \\
\hline & & Tidak tahu & 0 & $\%$ \\
\hline \multirow[t]{3}{*}{2} & \multirow{3}{*}{$\begin{array}{l}\text { Apakah bapak/ibu mengetahui pentingnya } \\
\text { menjaga kebersihan tangan dengan selalu } \\
\text { mencuci tangan menggunakan sabun }\end{array}$} & Tahu & 12 & $80 \%$ \\
\hline & & Ragu-ragu & 3 & $20 \%$ \\
\hline & & Tidak tahu & 0 & $0 \%$ \\
\hline \multirow[t]{3}{*}{3} & \multirow{3}{*}{$\begin{array}{l}\text { Apakah bapak/ibu mengetahui tata cara yang } \\
\text { benar ketika mencuci tangan }\end{array}$} & Tahu & 12 & $80 \%$ \\
\hline & & Ragu-ragu & 3 & $20 \%$ \\
\hline & & Tidak tahu & 0 & $0 \%$ \\
\hline \multirow[t]{3}{*}{4} & \multirow{3}{*}{$\begin{array}{l}\text { Apakah bapak/ibu pernah mendengar atau } \\
\text { mengetahui apa itu Paper soap (Sabun kertas) }\end{array}$} & Tahu & 14 & $93,3 \%$ \\
\hline & & Ragu-ragu & 1 & $6,67 \%$ \\
\hline & & Tidak tahu & 0 & $0 \%$ \\
\hline \multirow[t]{3}{*}{5} & \multirow{3}{*}{$\begin{array}{l}\text { Apakah bapak/ibu mengetahui cara membuat } \\
\text { Paper soap (sabun kertas) secara sederhana }\end{array}$} & Tahu & 10 & $60 \%$ \\
\hline & & Ragu-ragu & 6 & $40 \%$ \\
\hline & & Tidak tahu & 0 & $0 \%$ \\
\hline \multirow[t]{3}{*}{6} & \multirow{3}{*}{$\begin{array}{l}\text { Apakah bapak/ibu mengetahui cara } \\
\text { menggunakan Paper soap (sabun kertas) }\end{array}$} & Tahu & 14 & $93,3 \%$ \\
\hline & & Ragu-ragu & 1 & $6,67 \%$ \\
\hline & & Tidak tahu & 0 & $0 \%$ \\
\hline \multirow[t]{3}{*}{7} & \multirow{3}{*}{$\begin{array}{l}\text { Selain mencuci tangan, apakah bapak/ibu } \\
\text { mengetahui cara menjaga daya tahan tubuh } \\
\text { agar terhindar dari penularan wabah COVID- } \\
19\end{array}$} & Tahu & 12 & $80 \%$ \\
\hline & & Ragu-ragu & 3 & $20 \%$ \\
\hline & & Tidak tahu & 0 & $0 \%$ \\
\hline
\end{tabular}

Setelah pengaplikasian secara langsung pembuatan dan penggunaan sabun kertas kepada peserta pengabdian, diberikan kuisioner kedua dengan pertanyaan yang sama. Dari hasil kuisioner yang diberikan didapatkan hasil sebagian besar peserta sudah mengetahui bentuk penularan penyakit bisa melalui tangan, seluruh peserta pun 
Risky Hadi Wibowo,dkk. Penyuluhan Dan Pembuatan Paper Soap (Sabun Kertas) ...

mampu mengetahui pentingnya menjaga kebersihan tangan dengan sabun dan sudah mengetahui sabun kertas, baik dari cara membuat sabun kertas maupun cara menggunakan Paper soap (sabun kertas) yang benar dan tepat.

\section{SIMPULAN}

Dari hasil kegiatan pengabdian mengenai penyuluhan dan pembuatan sabun kertas kepada masyarakat dapat disimpulkan bahwa pengabdian tersebut dapat menjadi salah satu tindakan secara tidak langsung dalam mengurangi meningkatnya angka infeksi COVID-19 saat ini dilingkungan masyarakat khususnya warga Kelurahan Pematang Gubernur dengan meningkatkan kesadaran dalam membiasakan membersihkan tangan menggunakan sabun yang dibuat dalam bentuk yang menarik, penggunaannya fleksibel serta mudah dibawak kemana saja, dari respon umpan balik yang diberikan tim pelaksana pengabdian, menghasilkan respon positif terhadap kegiatan ini, yang awalnya belum mengetahui pembuatan dan penggunaan sabun kertas menjadi tahu akan hal tersebut. Diharapkan dari pelaksanaan program pengabdian ini dapat menjadi upaya pencegahan wabah COVID-19 di lingkungan sekitar serta menambah informasi baru dan keterampilan untuk para warga dalam membuat sabun yang menarik.

UCAPAN TERIMA KASIH
Penulis mengucapkan terima kasih kepada Lembaga Penelitian dan Pengabdian Masyarakat (LPPM) Universitas Bengkulu melalui hibah Pengabdian Kepada Masyarakat (PPM) Pembinaan Fakultas MIPA, Universitas Bengkulu nomor: 2579/UN30.12/HK 2020 tanggal 12 Agustus 2020, atas nama Risky Hadi wibowo, dan Peserta Pengabdian yaitu warga Kelurahan Pematang Gubernur, kota Bengkulu, RT.22, RW.02 serta semua pihak yang membantu menyukseskan acara pengabdian pada masyarakat ini.

\section{DAFTAR PUSTAKA}

Hammond B, Aii Y. 2000. Effect of hand sanitizer use on elementary school absenteeism. In: American Journal of Infection Control.

Joy, Jyothi M., AVS Praveen K., S Mohanalakshmi, dan S Prathyusha, 2012, Formulation and Evaluation of Poly Herbal Hand Wash, International Journal of Pharmacy, 2(2): 3943.

Noviana, M,. Musthafa,H., Putra, A. 2020. Pelatihan Pembuatan Hoopart Berbahan Kain Goni Dengan Ornamen Dayak Sebagai Pengembangan Ilmu ArsitekturBagi Guru-Guru Tk Áisyiyah Bustanul Athfal Samarinda Jurnal Pengabdian Masyarakat Borneo. 4 (1): 5158.

Salam RRS. 2003. Kualitas Sabun Mandi Cair dengan Penambahan Madu dan 
MARTABE : Jurnal Pengabdian Masyarakat Vol 4 No 1 Tahun 2021 Hal 317-324

Ekstrak Polen. Skripsi. Bogor:

llmu Produksi Ternak, FAPET, IPB.

Zhou, W. 2020. Buku Panduan

Pencegahan Coronavirus. Cina:

Physician of Wuhan Center For

Disease Control 